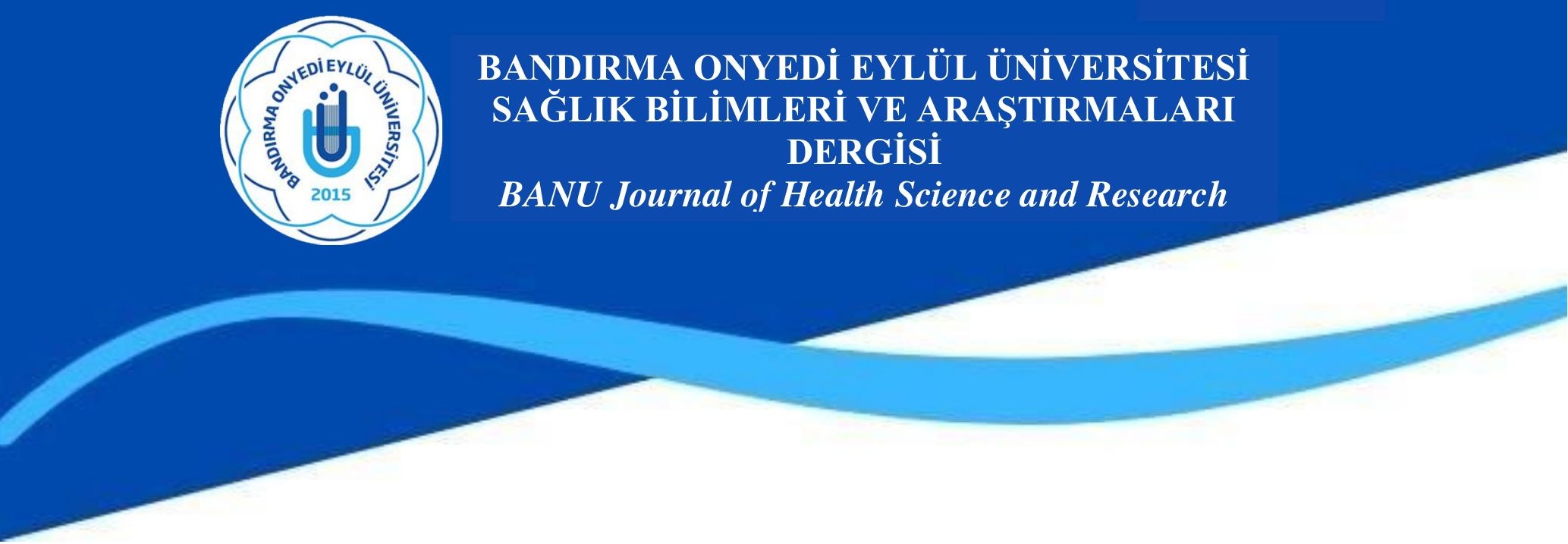

DOI: 10.46413/boneyusbad.957116

Derleme Makale / Review Article

\title{
Yaşlılarda Sarkopenik Obezite ve Güncel Beslenme Önerileri
}

Sarcopenic Obesity in the Elderly and Current Nutritional Recommendations
Büssra COLAK ${ }^{1}$
Seda CírTCi ${ }^{2}$

\section{${ }^{1}$ İmir Demokrasi Üniversitesi, Sağllk Bilimleri Enstitüsü, Beslenme ve Diyetetik Bölümü, Dyt}

\section{${ }^{2} \dot{I} z$ mir Demokrasi} Üniversitesi, Sağlık Bilimleri Fakültesi, Beslenme ve Diyetetik Bölümü, Dr. Öğr. Üyesi

Sorumlu yazar / Corresponding author: Büşra Çolak

busra_coolak@hotmail.c om

Geliș tarihi / Date of receipt: 24.06 .2021

Kabul tarihi / Date of acceptance: 10.11 .2021

Atıf/Citation: Çolak, B., Çiftçi, S. (2021). Yaşlılarda sarkopenik obezite ve güncel beslenme önerileri. BANÜ Să̆lık Bilimleri ve Araştırmaları Dergisi. 3(3), 208-221. doi: 10.46413/boneyusbad.95 7116

\section{ÖZET}

Yaşlılık dönemi, hastalık yükünün ve hastalıklara karşı direncin azaldığg, engellenemeyen biyolojik bir dönemdir. Yaşlanmayla birlikte sindirim sisteminde çiğneme, yutma, sindirme ve bağırsak hareketliliği gibi birçok fonksiyondaki değişiklikler besin alımını olumsuz etkilemektedir. Herhangi bir beslenme sorunu olmasa bile yaşla beraber iskelet kas kütlesi azalırken;

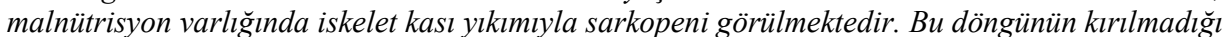
durumlarda daha farklı hastalıkların da eklenmesiyle bireyin sağlı̆̆ olumsuz etkilenmektedir. Iskelet kas fonksiyonunun zaylflamasiyla birlikte yaşlı bireylerin fiziksel aktivitesi ve enerji harcaması azalmaktadır. Buna eşlik eden abdominal yağlanma ile sarkopeninin yanında obezite de oluşabilmektedir. Sarkopenik obezite olarak adlandirılan bu durumda obezite kaynakl ortaya çıkan inflamasyon, iskelet kası yıkımını daha da artırmaktadır. Bu nedenle sarkopenik obezite, sarkopeninin tek başına varliğından daha tehlikelidir. Yaşlı bireylerde kas kütlesindeki azalmayla birlikte yă̆ kütlesindeki artış, gözle görülür değişiklik oluşmaması halinde sarkopenik obezite tanısının konmasını zorlaştırmaktadır. Yaşlıların ihtiyaç duyduğu besin ve besin ögelerinin, yaşlılığın getirdiği nedenlerle oluşan iştahsızlık ve yeme güçlüklerine göre modifiye edilerek, yeterli ve dengeli bir diyetle verilmesi gerekmektedir. Bu şekilde yaşlıları hem sarkopeniden hem de sarkopenik obeziteden koruyabilmek mümkündür. Bu makalede, sarkopenik obezite görülen yaşlı bireylerde beslenme müdahalelerinin sağllk üzerine etkileri ve güncel beslenme önerileri literatürdeki kanıta dayalı son yayınlar incelenerek derlenmiştir.

Anahtar kelimeler: Malnütrisyon, Obezite, Sarkopeni, Yaşlılık

\section{ABSTRACT}

The old age period is an inescapable biological era during which the burden of disease and disease resistance decreases as individuals gain more knowledge and experience. Many processes of the digestive system, such as chewing, swallowing, digestion, and intestinal motility, vary with age and have a negative impact on food intake. Skeletal muscle mass declines with age, even if there is no nutritional deficit, whereas sarcopenia is characterized by skeletal muscle degeneration in the presence of starvation. When this cycle is not disrupted, the individual's health suffers because of the accumulation of various diseases. Physical activity and energy expenditure in elderly people decline when skeletal muscle function deteriorates. Obesity may develop in conjunction with sarcopenia and abdominal adiposity. In this condition called sarcopenic obesity, obesity-induced inflammation further increases skeletal muscle destruction. As a result, sarcopenic obesity is more harmful than simply having sarcopenia. The fact that the net body weight does not change because of the loss of muscle mass and gain of fat mass in elderly people makes diagnosing sarcopenic obesity challenging. The nutrients and nutrients required by the elderly should be tailored to their loss of appetite and eating issues because of aging, and they should be supplemented with a nutritious and well-balanced diet. The elderly can be safeguarded from sarcopenia and sarcopenic obesity in this way. By reviewing the most recent evidence-based publications in the literature, the effects of dietary therapies on the health of elderly people with sarcopenic obesity and current nutritional recommendations are summarized in this article.

Keywords: Malnutrition, Obesity, Sarcopenia, Aging 


\section{GíRiş}

Yaşlanma, bir organizmada zaman içinde meydana gelen, metabolizmadaki yapım olaylarının yerini yıkım olaylarına bıraktığı ve bireylerin çeşitli hastalıklara daha açık hale gelmesiyle sonuçlanan kolektif fizyolojik değişiklikler dizisi olarak tanımlanabilmektedir (Barkoukis, 2016). Özellikle 60 yaş sonrası, vücutta yıkım olayları daha belirgin hale geldiğinden Dünya Sağlık Örgütü tarafından 60 yaş ve üzeri bireyler yaşlı olarak kabul edilmektedir (World Health Organisation [WHO], 2015). Dünya genelinde 60 yaş üzeri yaşlı nüfusunun 2030 yılında 1.4 milyara, 2050 yılında ise yaklaşı 2.1 milyara ulaşması beklenmektedir (Rath, 2019). Türkiye'de yaşl1 nüfus olarak kabul edilen 65 yaş ve üstü nüfus, 2015 yılında 6 milyon 495 bin 239 kişi iken son beş yilda \%22.5 artarak 2020 yılında 7 milyon 953 bin 555 kişi olmuştur. Yaşlı nüfusun toplam nüfus içindeki oranı ise 2015 yılında $\% 8.2$ iken, 2020 y1lında $\% 9.5$ 'e yükselmiştir. Nüfus projeksiyonlarına göre yaşlı nüfus oranının 2025 y1lında \%11.0; 2030 yılında \%12.9; 2040 yılında $\% 16.3 ; 2060$ y1lında \%22.6 ve 2080 yılında \%25.6 olacağ1 öngörülmektedir (Türkiye İstatistik Kurumu [TÜİK], 2020). Dünya Sağlık Örgütü 2015 verilerine göre ülkemizde doğumdan itibaren beklenen yaşam süresi kadınlarda ve erkeklerde sirasiyla 80.1 ve 75.4 ; ortalama ise 77.8 yıldır (WHO, 2017). Artan yaşlı nüfus ve yaşam süresinin uzaması ile birlikte yaşlılık döneminde daha çok karşılaşılan hastalıkların görülme sıklığının artması, sağlık ve refahı korumak için stratejilerin geliştirilmesini zorunlu hale getirmektedir (Rath, 2019).

Beslenme, sağlıklı yaşlanma için temel bir öneme sahiptir (Artaza-Artabe, Sáez-López, SánchezHernández, Fernández-Gutierrez ve Malafarina, 2016). Yaşlı bireylerde görülen çiğneme ve yutma bozukluğu nedeniyle ortaya çıkan yeme korkusu, boğulma hissi, yemek isteksizliği ile birlikte besin alımında yetersizlik yaşanmaktadır (Rusu ve ark., 2020). Tat yeteneklerinin bozulmasının yetersiz beslenme riskini $2.5 \mathrm{~kat}$, yutma güçlüğünün ise 5 kat artırdığ 1 belirtilmektedir (Corcoran, Murphy, Culligan, Walton ve Sleator, 2019). Yaşlanmaya bağlı oluşan iștahsızlık, enerji alımında ciddi bir azalma ile ilişkilidir. Azalan iştah ile azalan enerji alımı ve enerji harcaması, 20-70 yaşları arasında her on yilda bir dinlenme metabolizma hızında $(\mathrm{DMH})$ yaklaşı \%1 ile \%2'lik azalmaya sebep olmaktadır. (Barkoukis, 2016).
Kas kütlesi, gücü ve fiziksel fonksiyonunun yaşa bağl1 bir düşüşü olan sarkopeni; düşme, kırılganlık ve düşük yaşam kalitesi ile ilişkilidir (Bo ve ark., 2019). Kronik hastalık yükü fazla olan yaşlilarda yetersiz beslenme, morbidite ve mortalitenin artışına neden olduğundan yaşlılar için önerilen beden kütle indeksi (BKİ) değeri, mevcut alt sınır olan $18.5 \mathrm{~kg} / \mathrm{m} 2$ ' den daha yüksek $(21-22 \mathrm{~kg} / \mathrm{m} 2$ alt sinır) tutulmaktadir. Yaşlanmayla birlikte hem metabolizmanın yavaşlaması hem de fiziksel aktivitenin azalması ile yağsız vücut kütlesinde azalma görülürken, vücut yağ kütlesinde artış yaşanmaktadır. İstenmeyen vücut ağırlığı kaybıyla birlikte artan yağ kütlesi, vücut ağırlığında bir değişim oluşturmayacağından yağsız vücut kütlesi kaybı, vücut ağırlığı ölçümü ya da BKİ değeri hesaplamasıyla saptanamamaktadır (Barkoukis, 2016). Sarkopenik obezitesi olan kişilerde hem düşük kas kütlesi hem de yüksek vücut yağı bulunmakta olup metabolik hastalık riski sadece sarkopenik veya obez olan kişilere göre daha yüksektir (Hsu, Liao, Tsai ve Chen, 2019). Bu derlemede; yaşlı bireylerde sarkopenik obezite durumunun nedenleri, tarama yöntemleri ve yaşl1 bireyleri bu durumlardan koruma yolunda gerekli beslenme müdahalelerinin etkileri incelenmiştir.

\section{Yaşlılarda Malnütrisyon}

Yeterli ve dengeli beslenmenin sağlanması, sağlığın korunmasına ve kronik hastalık riskinin azaltılmasına yardımc olur. 'Yaşlanma anoreksisi', bireyler yaşlandikça ortaya çıkan, yaşlı bireylerin enerji alımlarını azaltan ve yetersiz beslenme olasılıklarını artıran yaşa bağlı değişiklikleri tanımlamak için kullanılan bir terimdir. Yaşa bağlı görülen iştahsızlık ve çiğneme-yutmada problemlerle birlikte besin alımında azalma, makro ve mikro besin ögelerinin de alımında azalmaya neden olmaktadır. Malnütrisyon yaşlı bireylerin morbidite-mortalite riskini ve hastaneye yatışını artırarak ilerleyen süreçte fiziksel engellilik ve başkasına bağımlılık durumu ciddi sağlık sorunlarını beraberinde getirmektedir, bu nedenle malnütrisyon varlığının en kisa sürede tespit edilmesi gerekmektedir (Sulmont-Rossé, 2020; Siddique, O'Donoghue, Casey ve Walsh, 2017). Amerika Parenteral ve Enteral Beslenme Derneği (American Society for Parenteral and Enteral Nutrition- ASPEN) ve Beslenme Akademisi'ne (Academy of Nutrition) göre, düşük enerji alımı, vücut ağırlığ kaybı, kas kütlesi kaybı, deri altı yağ kaybı, sıvı birikimi ve el kavrama gücünde düşüş kriterlerinden en az ikisinin varlığ 1 , bireyin yetersiz beslendiğini 
göstermektedir (Corcoran ve ark., 2019). Bu göstergelerin yanında malnütrisyon riskinin belirlenmesinde, doğrulanmış bir tarama aracı kullanılması önerilmektedir (Siddique ve ark., 2017). Hollanda' da gerçekleştirilen, Türkiye'nin de aralarında olduğu yedi ülkede yaşayan yaşlı bireylerde kullanılmak üzere doğrulanmış 22 malnütrisyon tarama aracı kullanılarak yapılan meta-analizde, yetersiz beslenme riskinin yaygınlığ 1 toplumda \%8.5 iken hastanede yatan yaşl1larda oran \%28'e kadar çıktığı gözlenmiştir (Leij-Halfwerk ve ark., 2019). Beslenme durumu tarama testleri arasında Mini Nütrisyonel Değerlendirme (Mini Nutritional AssessmentMNA), Malnütrisyon Evrensel Tarama Arac1 (Malnutrition Universal Screening Tool- MUST), Geriatrik Beslenme Risk İndeksi (Geriatric Nutritional Risk Index- GNRI) ve Nütrisyonel Risk Tarama-2002 (Nutritional Risk Screening2002- NRS-2002) tarama testleri bulunmaktadır (Corcoran ve ark., 2019). Yaşlılarda beslenme durumunun değerlendirilmesi için en çok kullanilan test olan MNA, antropometrik ölçümler, yaşam tarzı, besin tüketimi ve öznel sağlık değerlendirmesiyle ilgili bilgi almayı amaçlayan toplam 18 sorudan oluşmaktadır. MNA'daki ilk 6 sorunun yer aldığ 1 MNA-SF (MNA- kısa formu), daha hızlı bir değerlendirme yapabilmek amaciyla geliştirilmiştir. MNA puanlamasina göre 17 puan alt1, MNA-SF puanlamasına göre ise 7 puan ve altı yetersiz beslenme riski olarak kabul edilmektedir (Bauer, Kaiser, Anthony, Guigoz ve Sieber, 2008). MNA, şu anda yaşlilar arasında en geçerli test olarak kullanılmakta olsa da MNA'nın düşük özgünlüğü ve demans gibi iletişim sorunları olan yaşlı hastalar arasında MNA'y1 tamamlayamama gibi bazı dezavantajları bulunmaktadır (Abd Aziz, Mohd Fahmi Teng ve Kamarul Zaman, 2019). GNRI, yaşlılarda yetersiz beslenmenin tespitine ve beslenmeye bağlı morbidite ve mortalite riskinin nicel olarak belirlenmesine olanak sağlayan bir beslenme risk indeksidir. GNRI yaşl1larda kullanılmak için Beslenme Risk İndeksi (Nutrition Risk Index- NRI) değiştirilerek geliştirilmiş bir indekstir. Pratiktir ve sağlık hizmeti veren çoğu yerde, özellikle demans, konuşma ve algılama zorluğu yaşayan yaşlı hastalar arasında güvenilir değerlendirme sağlamaktadır. GNRI puanlaması [1.49 $\times$ albümin $(\mathrm{g} / \mathrm{L})]+[41.7 \times$ (güncel ağırlık/Lorentz formülüne göre ideal ağırlık)] formülü kullanılarak yapılmaktadır ve toplamda 82 puan altı puanın, beslenme ilişkili yüksek morbidite ve mortalite ile bağlantılı olduğu bildirilmektedir
(Bouillanne ve ark., 2005). Malezya'da bulunan bir hastanenin akut bakım servislerinde yatmakta olan, yaş ortalaması $68.9 \pm 8.4$ yıl olan 134 yaşlı hasta ile yürütülen kesitsel bir çalışmada Subjektif Global Değerlendirme (Subjective Global Assessment- SGA), MNA ve GNRI, onay veren tüm katılımcılarla yüz yüze görüşmeler yoluyla uygulanmıştır. Çalışmanın sonucunda katılımciların beslenme durumunu değerlendirmek için kullanılan GNRI'nın, MNA'ya göre daha kolay uygulanabilir olduğu ve daha doğru sonuç verdiği belirtilmiştir (Abd Aziz ve ark., 2019). GNRI puan hesaplamada kullanılan albümin gibi serum biyobelirteçlerin düşük özgünlükleri ve inflamasyon gibi durumlardan etkilenmeleri ile yetersiz beslenmenin teşhisinde veya izlenmesinde oynadığı rol, bazı durumlarda tartışmalıdır. Bununla birlikte, prealbümin gibi yarılanma ömrü kısa olan biyobelirteçler, beslenme yetersizliğinin belirlenmesinde daha doğru sonuç vermektedir (Keller, 2019).

\section{Yaşlılarda Sarkopeni}

Sarkopeni kelimesi orijinal olarak Yunanca'da kas kaybı anlamına gelmektedir ( $\operatorname{sarc}=$ et; penia = kayb1) (Morley, 2016). Kronik hastal1k durumu, yetersiz beslenme, yetersiz uyku ve fiziksel inaktivite gibi çeşitli faktörlerin varlığıyla bireylerde sarkopeni riski artmaktadır. Ayrıca, sigara ve alkol kullanımı ve serum D vitamini seviyesinin düşüklüğü de sarkopeni riskini artırmaktadır (Lim ve ark., 2018). Genel olarak vücudumuz 30 yaşında en yüksek kas kütlesine sahiptir. Kas kütlesi, yaşla hızlanan kas kaybıyla birlikte 40 yaşından itibaren kademeli olarak azalmaya başlamaktadır (Son, Yu ve Seo, 2019). Yaşlanma ile kas gücünün azalması fonksiyonel kapasite kaybına neden olmaktadır. Bu durum düşme ve sakatlık gibi olumsuz sağlık sonuçlarının önemli bir nedenidir. Yaşlı sayısı ve nüfus içindeki oranı artmaya devam ettikçe, sarkopeni ile ilişkili morbidite giderek artan bir sağl1k sorunu haline gelecektir (Morley, 2016).

Avrupa Yaşlılarda Sarkopeni Çalışma Grubu (European Working Group on Sarcopenia in Older People-EWGSOP2) tarafından yaşlı bireylerde sarkopeni varlığının tespiti için 4 aşamalı bir sistem geliștirilmiștir (Cruz-Jenfort ve ark, 2019). İlk aşama olan vakaların saptanması aşamasında basit ve hızlı bir sarkopeni tarama aracı olarak fiziksel aktivite yeteneğini ve düşme riskini sorgulayan SARC-F- (strength, assistance in walking, rise from a chair, climb stairs, falls) 
kullanımı önerilmektedir (Morley, 2016). İkinci aşama olan inceleme aşamasında, kas gücünü ölçmek amacıyla el kavrama gücü kesme değerleri kadınlarda $<16 \mathrm{~kg}$ ve erkeklerde $<27 \mathrm{~kg}$ (Dodds ve ark, 2014); 5 kere sandalyeden kalkıp oturma süresinin kesme değeri $>15$ s (Jones, Rikli, Beam, 1999) olarak belirlenmiştir. Üçüncü aşama olan onaylama aşaması kas gücü ve kas kütlesinin biyo-empedans analizi (BIA), el kavrama gücü, çift enerjili X-1şını absorptiometre (DEXA), bilgisayarlı tomografi (BT) ve manyetik rezonans (MR) gibi cihazlarla objektif ölçümlerini içermektedir. BT ve MR görüntüleme, vücut yağını diğer yumuşak dokulardan etkili bir şekilde ayırt edebildiği için bu iki ölçüm araştırmalarda kullanılan standart tekniklerdir ancak bu yöntemlerin hiçbiri sarkopeniyi değerlendirmek için yeteri kadar hassas veya spesifik değildir (Dhillon ve Hasni, 2017). Dördüncü aşamada sarkopeninin şiddetinin ölçümü için normal yürüyüş hızında yavaşlama $(<0.8 \mathrm{~m} / \mathrm{s})$ (Cruz-Jentoft ve ark., 2010) gibi fiziksel performans yöntemleri önerilmektedir. Ulusal Sağlık Enstitüleri Vakfı (The Foundation for the National Institutes of Health- FNIH) kadınlar için el kavrama gücü kesme değerlerini $<16 \mathrm{~kg}$, erkekler için $<26 \mathrm{~kg}$ olarak belirlemiştir (Studenski ve ark., 2014). Sarkopeni, Asya Sarkopeni Çalışma Grubu (AWGS) tarafından düşük kas kütlesi $(<7.0$ $\mathrm{kg} / \mathrm{m} 2$ erkeklerde ve $<5.4 \mathrm{~kg} / \mathrm{m} 2$ kadınlarda); düşük el kavrama gücü $(<26 \mathrm{~kg}$ erkeklerde ve $<18$ kg kadınlarda) ve/veya normal yürüyüş hızında yavaşlama $(<0.8 \mathrm{~m} / \mathrm{s})$ (Cruz-Jentoft ve ark., 2010) ile tanımlanırken obezite; BKİ, bel çevresi ve yağ yüzdesi ile tanımlanmıştır. Sarkopeni taramasında üst-orta kol çevresi, baldır çevresi ve deri kıvrım kalınlığ ölçümleri gibi antropometrik ölçümlerin kullanılması, bireylerde obezite varlığı nedeniyle sarkopeni tanisinda hataya neden olabilmektedir (Khor ve ark, 2020).

Malnütrisyon-sarkopeni sendromu, özellikle yaşlı bireylerde malnütrisyon ve sarkopeninin bir arada varlığını vurgulayan durum için geliştirilmiş bir terimdir. Her iki durumda da tek başına olan duruma kıyasla artmış bir mortalite riski bulunmaktadır. Malnütrisyon-sarkopeni sendromu için her beslenme tarama testinin kendi içinde zayıf ve güçlü yönü bulunmaktadır. Örneğin Avrupa Parenteral ve Enteral Beslenme Derneği (European Society for Parenteral and Enteral Nutrition- ESPEN) tarafindan önerilen MNA, disfaji ve protein alımı açısından diyet kalitesini sorgulamakta ve sarkopenik obeziteyi obeziteden ayırt etmede yetersizdir (Juby ve Mager, 2019). Kırılganlık, yaşlı bireyin hastalık ile ilişkili stresörlere yüksek oranda maruz kalmasını ve hastalığın etkilerine açık olmasını ifade etmektedir (Abd Aziz ve ark., 2019). Yaşlılarda sarkopeni kırılganlığın başlica nedenidir. Kırılganlık tarama arac1 olarak yorgunluk, dayaniklılık ve aerobik egzersizlerde zorlanma, hastalık ve vücut ağırlığı kaybı durumunu sorgulayan FRAIL (fatigue, resistance, aerobic, illness, loss of weight) kullanılmaktadır. Kırılganlığın tedavisi, egzersiz, beslenme ve uyku durumu ile birlikte çoklu ilaç kullanımını düzenlemeyi içermektedir (Morley, 2016).

Protein ve D vitamini, sarkopeni ilişkisi açısından en çok araştırılan besin ögeleri arasındadır ve çeşitli randomize kontrollü çalışmalar, sarkopeniyi önlemede ve kas korunumunda proteinin kritik bir rol oynadığını vurgulamaktadır (Ganapathy ve Nieves, 2020; Park ve ark., 2018; Reinders ve ark., 2020; Verlaan ve ark., 2018). Yaşlı bireylerde kas kütlesi korunumu için günlük 1-1.2 g/kg/ gün protein alımı önerilmektedir. Akut veya kronik hastalığı olan yaşlı bireylerde katabolizmadaki artış nedeniyle protein alımı 1.2-1.5 g/kg/güne çıkarılabilmektedir (Bauer ve ark., 2013). Kırılgan yaşl1larda, üç ana öğün içerisinde (25-30 g/öğün) dengeli bir protein dağılımı ve 800 IU/gün'den fazla D vitamini uygulamasının, iskelet- kas sistemi sağlığını koruduğu, düşme ve kırık riskini azalttığı rapor edilmiştir (ArtazaArtabe ve ark., 2016). Yaşlı bireylerde D vitamini düzeyinin iyileştirilmesinin kas kütlesi ve kas gücü ile ilişkisinin araştırıldığı çalışmada D vitamini eksikliği olan aşırı kilolu ve obez 128 bireye altı ay boyunca haftada üç kez alması gereken 10.000 IU D vitamini veya plasebo tablet verilmiştir. Çalışmanın sonunda plasebo ile karşılaş̧tırıldığında, D vitamini takviyesi alan grubun apandiküler iskelet kas kütlesinde anlamlı iyileşmeler görülürken, el kavrama gücünde anlamlı bir iyileşme gözlenmemiştir. Müdahale grubundaki normal vücut ağırlığındaki bireylerdeki kas kütlesindeki artış obez bireylere kıyasla daha yüksek bulunmuştur (El Hajj, Fares, Chardigny, Boirie ve Walrand, 2018).

Kas yıkımının arttığı yaşlılık döneminde egzersiz kas proteini yapım hızını desteklerken protein alımıla birlikte sinerjik bir etki oluştuğu görülmektedir (Artaza-Artabe ve ark., 2016). Bununla birlikte, yaşlilarda, egzersize ve protein alımına verilen yanıt, genç bireylere kıyasla daha azdır ve bu duruma da "anabolik direnç" 
denilmektedir. Bu anabolik direnci önlemek için, $\geq 65$ yaş bireylerde daha yüksek bir protein alımı önerilmektedir (Dupont, Dedeyne, Dalle, Koppo ve Gielen, 2019). Sarkopeni veya kırılganlık riski yüksek olan yaşlı yetişkinlerde kas kütlesi ve performansını artırmaya yönelik çalışmaların yer aldığı bir sistematik derlemede kas germe egzersizinin yanında verilen protein takviyesinin, sadece egzersiz yapılmasina göre kas fonksiyonunun iyileştirilmesinde daha etkili olduğunu saptanmıştır (Liao, Chen, Huang ve Liou, 2019). Direnç egzersizi yapan obez yaşlı bireylerde protein takviyesinin vücut kompozisyonu ve fiziksel performans üzerine etkisini incelemeyi amaçlayan meta-analiz çalışmasında, protein takviyesinin direnç egzersizi ile uygulaması, sadece direnç egzersizi ile karşılaştırıldığında, yaşlı bireylerde yaşlanmaya bağlı kas kütlesindeki azalma ve bacaklarda güç kaybını önlemede daha güçlü etkiye sahip olduğu gösterilmiştir. Bu nedenle beslenme ve egzersiz stratejileri ile birlikte yaşlı popülasyonda kas kaybını önlemek için disiplinler arası pratik bir yaklaşım sergilenmesi önerilmektedir (Liao ve ark., 2017). Aminoasitler arasında dallı zincirli aminoasitlerin, özellikle de lösin aminoasidinin insülin varlığında kas protein yapımına etkisi daha fazladır. Bu nedenle protein alımını artırmak amacıyla önerilen takviyelerde çoğunlukla, dallı zincirli aminoasitlerden zengin olan peynir altı suyu proteini tercih edilmektedir (Nie, He, Zhang, Zhang ve Ma, 2018). Peynir alt1 suyu proteiniyle zenginleştirilmiş protein takviyesinin kas fonksiyonu ve fiziksel performans üzerine 12 ay süreyle uzun süreli etkisini değerlendirmeyi amaçlayan randomize kontrollü çalışmada sarkopenisi olan 74 yaş üzeri toplam 218 birey; kontrol grubu, plasebo grubu ve $2 \times 20 \mathrm{~g} /$ gün peynir alt1 suyu proteini ile zenginleştirilmiş protein takviyesi alan grup olmak üzere 3 gruba ayrılmış ve çalışma sonrası 43 ay süresince takip edilmiştir. Bireylere ev egzersizleri önerilip, $20 \mathrm{mg} /$ gün $\mathrm{D}$ vitamini takviyesi yapılmıştır. Sonuçta, sarkopenisi olan yaşlı kişilerde evde düşük yoğunluklu fiziksel egzersizle birlikte peynir altı suyu proteini ile zenginleştirilmiş protein takviyesi alımının, kas ve fiziksel performansta anlamlı bir iyileşme sağlamadığı rapor edilmiştir (Björkman ve ark., 2020).

Bireylerde yaşlanma ile ilişkili olarak kronik düşük dereceli inflamasyon gözlenmektedir. Uzun süreli kronik inflamasyon durumu da yaşlı bireylerde sarkopeni gelişimini hızlandırabilmektedir (Dupont ve ark., 2019) Randomize, çift kör, plasebo kontrollü toplam 60 sarkopenik yaşlı yetişkinle altı ay süreli düzenlenen çalışmada peynir altı suyu proteini (22 g/gün) ile D (702 IU/gün) ve E (109 mg/gün) vitaminlerinin kombine takviyesinin, sarkopenili yaşlı bireylerde kas gücü ve IGF-1 (insülin benzeri büyüme faktörü-1) ve IL-2 (interlökin-2) gibi anabolik belirteçleri önemli ölçüde iyileștirebileceği gösterilmiştir (Bo ve ark., 2019). Yaşlanmayla birlikte dolaşımda artan reaktif oksijen türlerinin, iskelet kas lifleri ve protein sentezi üzerine olumsuz etkilerini azaltabilmek için diyet antioksidanları (A, C, E vitaminleri, çinko, selenyum ve karotenoidler); lipit peroksidasyonunu önleme ve kollajen oluşumu gibi önemli roller üstlenmektedir. Diyetle antioksidan alım düzeyinin kadınlarda kas fonksiyonu üzerine etkisini inceleyen bir kesitsel çalışmada, antioksidan vitaminlerin ve özellikle C vitamininin diyetle daha yüksek miktarda alımının hem iskelet kası kütlesi kaybına hem de yaşlanma sırasında güç kaybına karşı koruyucu olabileceğgi bildirilmektedir (Welch, Jennings, Kelaiditi, Skinner ve Steves, 2020).

Yaşlı bireylerde mikro besin ögesi alımı ve sarkopeni oluşumu ile ilişkili kesitsel çalışmalarda; magnezyum, selenyum, D ve B12 vitaminlerinin (Verlaan ve ark, 2017), $\beta$-karoten ve $C$ vitamininin (Martin ve ark., 2011), potasyum, magnezyum, demir, kalsiyum, $\mathrm{E}$ ve $\mathrm{C}$ vitaminlerinin (Beaudart, Locquet, Touvier, Reginster ve Bruyère, 2019) diyetle yeterli düzeyde alımının, fiziksel aktivite ve kas performansında artışla ilişkili olduğu bildirilmiştir. Ayrıca randomize kontrollü bir çalışmada yaşlı bireylere 12 hafta süreyle verilen $300 \mathrm{mg} /$ gün magnezyum takviyesinin, çalışmanın sonunda müdahale grubunda yürüme hızını ve sandalyeden kalkıp oturma süresini iyileştirdiği görülmüsstür (Veronese ve ark., 2014). Antiinflamatuar özellikte olduğu bilinen omega-3 yağ asitleri hem randomize kontrollü çalışmalarda hem de kohort analizlerinde, kas kütlesinin korunmasında ve yaşlı bireylerde normal düşüşe karş1 korunmada önemli görülmüştür (Dupont ve ark., 2019; Ganapathy ve Nieves, 2020; Seino ve ark., 2018). Omega-3 diyet alımı için belirlenmiş bir Diyet Referans Alım düzeyi olmasa da eikosapentaenoik asit (EPA)+ dokosaheksaenoik asit (DHA) için yeterli alım miktarı $250 \mathrm{mg} /$ gün, alfa-linolenik asit (ALA) için diyet enerjisine katkısının \%0.5 kadar olması önerilmektedir (European Food Safety Authority [EFSA], 2019). 
Diyetle alınması önerilen EPA + DHA miktarına ulaşabilmek için; haftada en az 2-3 kez, toplam 350-400 g balık tüketimi tavsiye edilmektedir (Besler ve ark., 2015).

\section{Yaşlılarda Obezite ve Sarkopenik Obezite}

Obezite, vücutta yağ kütlesinin anormal şekilde artışı olarak tanımlanmaktadır. Son zamanlarda prevalansı, dünya çapında orta yaşlı ve yaşlı yetişkinlerde dramatik bir şekilde artmaya devam etmektedir. Yaşlı obezitesi, genetik, epigenetik ve çevresel faktörlerden etkilenen enerji alımı ve harcaması arasındaki uzun süreli dengesizlikten kaynaklanan çok faktörlü bir durumdur (Kim, 2018). Vücut ağırlığ fazlalığının ve obezitenin, yaşlılarda kardiyovasküler hastalık ve mortalite üzerindeki etkileri konusunda tartışmalar vardır. $\mathrm{Bu}$ tartışmalardan biri, "obezite paradoksu" olarak adlandırılan, BKİ ile ölçülen vücut ağırlığı fazlalığı ve obezitenin, görünüşte azalmış bir mortalite riskiyle ilişkili olma durumudur. 65 yaş ve üzeri yaklaşık 200.000 kişiden oluşan 32 çalışmayı içeren bir meta-analizde BKİ ile mortalite arasındaki ilișki incelendiğinde en düşük risk, 24 ile $30 \mathrm{~kg} / \mathrm{m} 2$ arasındaki BKİ değerinde bulunurken; BKİ'nin $33 \mathrm{~kg} / \mathrm{m} 2$ 'yi aştı̆̆ında mortalite riskinin artmaya başladığ 1 gözlenmiş ve BKİ ile mortalite arasında " $U$ " şeklinde bir ilişki olduğu belirlenmiştir (Atkins ve Wannamathee, 2020). Abdominal yağ birikimine ek olarak, vücuttaki en büyük insülin duyarlı hedef doku olan iskelet kasının kaybı insülin direncine yol açmakta ve böylece kas kaybı ile yağlanma arasında kısır bir döngü oluşmaktadır. Ayrıca, abdominal yağlanma insülin direncini daha da artıran ve kaslar üzerinde potansiyel olarak doğrudan katabolik etkileri olan proinflamatuar adipokin ve oksidatif stres seviyelerini artırmaktadır. İnsülin direncine ek olarak yaşın ilerlemesiyle kadınlarda östrojen, erkeklerde testosteron seviyesinin azalması gibi değişiklikler de bu duruma neden olmaktadır. Ayrıca, yaşlanmaya birlikte genellikle BKI'si sabit bireylerde bile ilerleyici kas kütlesi ve gücünde kayıp ve yağ kütlesinde bir artış görülmektedir (Kim, 2018).

Sarkopenik obezite terimi ilk olarak Baumgartner ve arkadaşları tarafindan (2000) yeni bir vücut kompozisyonu kategorisi olarak adlandırılmıștır ve hem sarkopeni hem de obezitenin vücut kompozisyonu kategorilerini birleştirmektedir. Yapılan bir çalışmada sarkopenik obez bireylerin, tek başına sarkopenik veya obez olan bireylerden daha yüksek kardiyovasküler risk etmenlerine ve mortalite riskine sahip olduğu gösterilmiştir (Atkins ve Wannamathee, 2020). Zhang ve arkadaşlarının (2019) yaptığı çalışmada, sarkopenik obeziteye sahip kişilerde normal vücut bileşimine sahip kişilere kıyasla mortalite riskinin 1.2 kat arttığı bulunmuştur (Zhang ve ark., 2019). Ayrıca, kas zayıflığının kronik hastalıkla ilişkili olduğu ve diyabet, kardiyovasküler hastalık gibi kronik hastalıkların da kas gücünde azalmaya neden olduğu bildirilmektedir. $\mathrm{Bu}$ nedenle sarkopeni bir hastalığı ortaya çıkarabilmekte ya da sarkopeni altta yatan bir hastalık nedeniyle kötüleşebilmektedir (Lim ve ark., 2018). Yaşlı bireylerde vücut kompozisyonunun değişimi ile kemik mineral yoğunluğu arasındaki ilişkiyi incelemek amaciyla yürütülen 80 yaş üzeri 128 bireyin yer aldığ 1 kesitsel bir çalışmada sarkopenili yaşlı bireylerde obez bireylere kıyasla daha düşük kemik mineral yoğunluğu ve omurgada daha yüksek osteopeni/osteoporoz riski olduğu saptanmıştır. Yağsız kütlenin kemik mineral yoğunluğu (total, femur ve omurga) ile doğrudan ilişkili olduğu ve obezitenin omurgada osteopeni/osteoporoz için koruyucu bir faktör olduğu sonuçlarına ulaşılmıştır (Santos, Christofaro, Gomes, Júnior ve Gobbo, 2018)

Sarkopeni, obezite ve sarkopenik obezite ile ilişkili durumlara yer verilen kesitsel çalışma örnekleri Tablo 1'de özetlenmiştir. Türkiye'de yapılan kesitsel bir çalışmada 65 yaş üzeri toplam 423 bireyin antropometrik profilleri incelendiğinde sarkopenik, obez ve sarkopenik obez bireylerin prevalansının sirasıla \%14, \%35 ve \%11 olduğu tespit edilmiştir. En düşük ortalama yürüyüş hızı ve el kavrama gücü değerleri ve en yüksek düşme riski sarkopenik obez grupta görülmüştür (Öztürk ve ark., 2018). 2008-2011 yılları arasında Kore Ulusal Sağlık ve Beslenme Araştırması verileri kullanılarak 65 yaş üzeri toplam 3492 birey vücut bileşimine göre ayrılmış, sağlık davranışı, besin alımı ve kronik hastalık durumları karşılaştırılmıştır. Sonuçlara göre egzersiz yapma oran1 sarkopenisi ve sarkopenik obezitesi olan gruplarda anlaml olarak daha düşük bulunurken; diyetle günlük enerji, protein, yağ alımının ve kronik hastalık riskinin sarkopenik obezitesi olan bireylerde daha yüksek olduğu belirlenmiştir (Lim ve ark., 2018). Aynı çalışmanın 3367 yaşlı birey üzerindeki verileriyle gerçekleştirilen başka bir çalışmada, bireyler apandiküler iskelet kas kütlesi ile sarkopeni; bel çevresi ile obezite için değerlendirilmiştir. Diyetle günlük enerji alımı, sarkopenisi olmayan bireylerde daha yüksek 
bulunmuştur. Sarkopenisi olan bireylerde diyetle daha düşük enerji alımı görülürken önerilen enerji, riboflavin ve $\mathrm{C}$ vitamini alımlarını karşılamayan gönüllülerde sarkopenik obezite riski de daha yüksek bulunmuştur (Son ve ark., 2019). Üç farklı huzurevinde yaşayan 316 yaşlı birey çalışmaya dahil edilip sarkopeni taraması amaciyla apandikal iskelet kasi indeksi (appendicular skeletal muscle mass- ASMI), el kavrama gücü ve hareket kabiliyetleri ölçülmüştür. Sarkopeni sıklığ $\% 28.8$ olarak bulunup sarkopenik hastaların kontrollere göre daha yaşl1 olduğu görülmüştür. Sarkopeni prevalansı diyetteki hayvansal protein tüketimi ile ters ilişkili bulunmuştur ve artan BKİ'nin sarkopeniden koruyucu olabileceği rapor edilmiştir (Yang ve ark., 2019). Bu çalışmalardan bireylerin, yaşlanmayla birlikte sarkopeni ve sarkopenik obezite tehdidi altında olduklar1; yeterli düzeyde fiziksel aktivite ve yeterli makro ve mikro besin ögelerinin alınması ile hem sarkopenik obezitenin hem de onun yol açacağ kronik hastalıklarının önüne geçilebileceği sonucuna varılabilmektedir.

Tablo 1.Yaşıı Bireylerde Vücut Bileşimine Göre Karşılaştırma Yapan Kesitsel Çalışma Örnekleri

\begin{tabular}{|c|c|c|c|c|c|c|}
\hline \multirow[b]{2}{*}{ Yazar } & \multirow[b]{2}{*}{ Örneklem } & \multirow[b]{2}{*}{ Yaş (yıl) } & \multirow[b]{2}{*}{$\begin{array}{l}\text { Değerlendirme } \\
\text { Yöntemleri }\end{array}$} & \multicolumn{3}{|c|}{ Bulgular } \\
\hline & & & & Sarkopenik & Obez & $\begin{array}{l}\text { Sarkopenik } \\
\text { Obez }\end{array}$ \\
\hline $\begin{array}{l}\text { (Öztürk } \\
\text { ve ark., } \\
2018)\end{array}$ & 423 kişi & $71.8 \pm 6$ & $\begin{array}{l}\text { TGUG } \\
\text { Hand grip } \\
\text { SMMI }\end{array}$ & $\begin{array}{l}\text { BKİ, bel ve } \\
\text { kalça çevresi } \downarrow\end{array}$ & $\begin{array}{l}\text { Fiziksel } \\
\text { fonksiyon ve } \\
\text { mental sağllk } \downarrow\end{array}$ & $\begin{array}{l}\text { Yürüme hızı ve } \\
\text { el kavrama } \\
\text { gücü } \downarrow \text { Düşme } \\
\text { riski } \uparrow\end{array}$ \\
\hline $\begin{array}{l}\text { (Lim ve } \\
\text { ark., } \\
\text { 2018) }\end{array}$ & 3492 kişi & $68.8 \pm 8.2$ & $\begin{array}{l}\text { DEXA } \\
\text { Bel çevresi } \\
\text { ASMM }\end{array}$ & Egzersiz $\downarrow$ & Egzersiz $\uparrow$ & $\begin{array}{l}\text { Egzersiz } \downarrow \\
\text { Diyet enerji- } \\
\text { protein yağ } \\
\text { alımı } \uparrow \\
\text { Diyabet ve } \\
\text { dislipidemi } \uparrow\end{array}$ \\
\hline $\begin{array}{l}\text { (Son ve } \\
\text { ark., } \\
\text { 2019) }\end{array}$ & 3367 kişi & $71.9 \pm 0.4$ & $\begin{array}{l}\text { DEXA } \\
\text { ASMM }\end{array}$ & $\begin{array}{l}\text { Diyet enerji } \\
\text { alımı } \downarrow \\
\text { ASMM } \downarrow\end{array}$ & $\begin{array}{l}\text { Diyet enerji } \\
\text { alımı } \uparrow\end{array}$ & $\begin{array}{l}\text { Diyet enerji, } \mathrm{B}_{2} \text {, } \\
\mathrm{C} \text { vit alımı } \downarrow\end{array}$ \\
\hline $\begin{array}{l}\text { Yang ve } \\
\text { ark, } \\
\text { 2019) }\end{array}$ & 316 kişi & $81.7 \pm 9$ & $\begin{array}{l}\text { ASMM } \\
\text { Hand grip }\end{array}$ & $\begin{array}{l}\text { Diyet hayvansal } \\
\text { protein alımı } \downarrow\end{array}$ & & Egzersiz $\uparrow$ \\
\hline
\end{tabular}

Kısaltma: $\uparrow$ : Diğer gruplarla karşılaştırıldığında daha düşük, $\downarrow$ : Diğer gruplarla karşılaştırıldığında daha yüksek, TGUG: timed up and go test, SMMI: iskelet kas indeksi (kas kütlesi (kg)/ boy (m2), ASMM: apendiküler iskelet kas kütlesi

\section{Yaşılıarda Sarkopenik Obezitenin Önlenmesinde Sağlıklı Beslenme Önerileri}

Sağl1klı yaşlanma için yeterli ve dengeli beslenme kilit rol oynamaktadır, ayrıca yaşı nüfusun her geçen gün artması; yaşlıların sağlıklı, yeterli ve dengeli beslenmesinin ne kadar önemli olduğunu göstermektedir. Yaşl1lık döneminde birçok nedene bağlı olarak yeterli ve dengeli beslenmenin sağlanamaması, yaşlı bireylerde sarkopeniye neden olduğu gibi obeziteye de neden olabilmektedir. Yetersiz beslenme sarkopeni gibi vücuda ciddi hastalık yükü getiren bir duruma sebep olurken, aşırı beslenme sonucu ortaya çıkan obezite de sağlık riskleri açısından istenilmeyen bir durumdur (Baum, Kim ve Wolfe, 2016).

Kas kütlesi korunumunda fiziksel aktivitenin öneminin yanı sira yeterli enerji ve mikro besin ögesi alımı, sarkopeni ve sarkopenik obezitenin önlenmesinde önemli rol oynamaktadır (Son ve ark., 2019). Yaşlılarda diyet proteini, özellikle kas kütlesinin korunması açısından alımına vurgu yapılan en önemli besin ögesidir. Kas protein sentezinin gerçekleşmesinde gerekli eşik miktarın gün boyunca ögünlere dağılmasının, sadece bir öğünde daha yüksek protein alınmasına göre anabolizmay1 daha fazla etkileyebileceği düşünülmektedir. Yaş aralığ 1 50-85 olan erkek ve kadınlarda protein alımını araştıran bir çalışmada, her ana ögünde $30 \mathrm{~g}$ protein alan katılımcılarda daha yüksek kas kütlesi ve kas gücü bildirilmiştir (Cardon-Thomas, Riviere, Tieges ve Greig, 2017). Bu nedenle sadece toplam protein alım miktarı değil, aynı zamanda yüksek protein içeren (30 g üstü) öğünlerin sayısı da kas kütlesi ile ilişkilidir (Hayashi ve ark., 2020). Kas protein sentezinin en yüksek düzeyde uyarılması için özellikle kaliteli protein kaynağı olan hayvansal kaynaklı besinlerin de diyete dahil edilmesi 
gerekmektedir (Baum ve ark., 2016). Yaşlı bireylerde anabolik direnci kurabilmek için günlük alınması gereken proteinin \%60'ının iyi kaliteli hayvansal proteinlerden sağlanması önerilmektedir (Kiesswetter, Sieber ve Volkert, 2020).

Hayvansal proteinler bitkilerden daha yüksek PDCAA (Protein Digestibility Corrected Amino Acid Score- Protein Sindirilebilirliği Düzeltilmiş Amino Asit Skoru) puanlarına sahiptir ve bu nedenle kas yapım sürecinde daha yüksek verimlilik sağlayabilmektedir. Hayvansal besinler protein dişında hem-demir, B12 vitamini, kreatin, taurin, omega-3 ve konjuge linoleik asitleri de içermektedir fakat doymuş yağ asitlerini de içerdiğinden kardiyovasküler hastalık ve dislipidemi durumlarında yağ miktarına dikkat edilerek tüketilmelidir (Lonnie ve ark., 2018). Hayvansal kaynaklı besinlerin yeterli miktarda tüketilmediği ya da tüketiminin tercih edilmediği durumlarda protein kalitesini artırmak amaciyla tahılların bakliyatlar veya süt ve süt grubu besinlerle tüketimi ya da yemeklere yumurta eklenmesi, diyetin protein kalitesini artırmaktadır.

Yaşlanmayla birlikte tüm kaslarda olduğu gibi yutma kaslarının da işlevinin azalmasıyla bireylerde disfaji ve aspirasyon riski artmaktadır ve son dönemde yaşlilarda disfajinin nedeni olarak sarkopeniye işaret edilmektedir (Maeda ve Akagi, 2016). Sarkopenik disfaji olarak adlandırılan durumda tüm vücuttaki iskelet kaslarının yanında yutma kaslarını da etkileyen bir fonksiyon kaybı görülmektedir. Disfaji ve malnütrisyon kısır döngüsüne aspirasyon kaynaklı pnömoni eklendiğinde oluşan inflamasyon, klinik tablonun daha kötüye gitmesine sebep olmaktadır. Sarkopenisi olan yaşlı erişkinlerde $30 \mathrm{kcal} / \mathrm{kg} /$ gün ve üzeri enerji alımı ve ideal vücut ağırlığına göre $1.2 \mathrm{~g} / \mathrm{kg} / \mathrm{gün}$ ve üzeri protein alımının çiğneme gücünün artmasında etkisi olacağı rapor edilmiştir (Wakabayashi ve ark., 2021). Çiğneme ve yutma güçlüğü olan bireylerde beslenmenin sağlanabilmesi için içeriği modifiye edilmiş ürünler ile daha iyi çiğnenip yutulabilen; iyi pişmiş, kesilmiş ve püre haline getirilmiş yemekler hazırlanmalıdır. Birçok nedene bağlı olarak gelișen yaşlilikta anoreksi durumunu önlemek için yemeğin sosyal ortamda yenilmesi, fiziksel özelliğinin duyulara hitap edecek şekilde hazırlanması ve servis edilmesi gibi çözümler getirilmelidir (Sulmont-Rossé, 2020)
Yaşlı bireylerde vücut kompozisyonu değişimi ve azalan fiziksel aktivite nedeniyle enerji gereksinimleri daha düşük olma eğilimindedir ancak birçok besin ögesi gereksiniminde bir azalma olmamaktadır. Oluşan bu durum, daha düşük enerjili, daha besleyici ve daha kolay tüketilebilir, yoğun bir beslenme örüntüsüne ihtiyaç duyulmasına neden olmaktadır (Clegg ve Williams, 2018).

Amerika Beslenme Rehberi'nin 2020-2025 baskısında yaşı bireyler için yapılan önerilerde, her besin grubundan besleyici değeri yüksek besinlerin uygun porsiyonlarda tüketilmesinin önemi vurgulanmaktadır. Yaşlı bireylere diyetlerinde çeşitli renklerde meyve, sebze, tam tahıllı ürünler, süt ürünleri ve kaliteli protein kaynaklarına daha çok yer vermeleri; eklenmiş şeker, doymuş yağ ve tuz alımlarını azaltmaları önerisinde bulunulmaktadır. Yaşlılık döneminde beslenme durumu incelendiğinde, protein ve B12 vitaminin yetersizliğinin diğer besin ögelerine göre daha fazla eksikliği görüldügüü rapor edilmektedir. Bu eksikliğin giderilmesi yönünde, protein alımının artırılmak amaciyla daha az tüketilme eğilimi olan kurubaklagillerin, yemeklerin içinde karışık şekilde tüketilmesiyle hem alınan protein miktarının hem de kalitesinin artırılabileceğine yer verilmektedir (USDA, 2020). Diyette protein miktarını artırılması amaciyla hayvansal proteinin yanında bitkisel proteini de artırması ile diyet posası alımında da artış görülmektedir (Prokopidis, Cervo, Gandham ve Scott, 2020). Avrupalı yaşlı yetişkin kohortunun alındığı NU-AGE (Nutrition in AgeYaşlilıkta Beslenme Stratejileri) çalışmasında yeterli diyet posası alımının yaşa bağlı kas kaybını azaltabileceği belirtilmiştir (MontielRojas ve ark., 2020).

Susama duyusunun azalmasıyla sıvı tüketiminin 60 yaş ve üzeri bireylerde azaldığı ve yaşlı bireyleri dehidrasyondan korumaya yönelik su, az yağlı ya da yağsız süt, çorba, \%100 sebze-meyve suları veya su içeriği yüksek sebze-meyve tüketiminin teşvik edilmesi gerekliliği vurgulanmaktadır (USDA, 2020). Türkiye'ye Özgü Beslenme Rehberi'nde (TÜBER) yaşlılar için $1.1 \mathrm{ml} / \mathrm{kkal} \mathrm{s} ı \mathrm{v} 1$ alımı önerisi yapılırken (Besler ve ark., 2015) Avrupa Gıda ve Güvenlik Ajans1 (European Food Safety Authority- EFSA) ise erkekler için 2.5 litre/gün, kadınlar için 2 litre/gün sıv1 alımı önermektedir ancak miktar, kullanılan ilaçlara ve hastalık durumuna göre özelleştirilmelidir (Picetti ve ark., 2017). 
Türkiye Beslenme Rehberi 2015 verilerine göre yaşl1l1k döneminde beslenmenin yeterli ve dengeli şekilde sağlanabilmesi için her besin grubundan besinin günlük olarak tüketilmesi ve gün içinde en az 3 öğün tüketilmesi gerekmektedir. Yağ tüketiminde öncelikli tercih bitkisel yağlar ve yağlı tohumlardan yana olmalıdır. Kemik sağlığı kalsiyum kaynağı süt ve süt ürünleri tüketimiyle desteklenmeli, tuz ve şeker alımı en aza indirilmelidir. 65 yaş üstü bireyler için günlük $\mathrm{D}$ vitamini alım miktarı 600 IU, kalsiyum alım miktarı $950 \mathrm{mg}$, demir alım miktarı $11 \mathrm{mg}$ kadar önerilmektedir. Bağırsak hareketliliğini artırmak ve kan glikozu ve kolesterolü üzerine olumlu sağlık etkileri sebebiyle posa alımı artırılmalı, bunun için de sebze-meyve ve tam tahıllı besinlerin tüketimine önem verilmelidir (Türkiye Cumhuriyeti Sağlık Bakanlığı, 2016). Türkiye'ye Özgü Beslenme Rehberi'ne göre yaşl111k döneminde bireylerin 4 porsiyon süt grubu, 2.5-3 porsiyon et grubu, 4-5 porsiyon ekmek ve tahıl grubu ve 5 porsiyon sebze-meyve grubu besinlerden tüketmesi yeterli ve dengeli beslenmenin sağlanabilmesi açısından gereklidir (Besler ve ark., 2015).

Tablo 2. Yaşlı Bireylerde Besin Ögelerinin Günlük Yeterli Alım Düzeyi Önerileri

\begin{tabular}{|c|c|c|}
\hline Besin Ögesi & Yeterli Alım Miktarı (AI) & Güvenilir Alım Düzeyi (RDI) \\
\hline Protein & - & $0.8-1 \mathrm{~g} / \mathrm{kg} / \mathrm{gün} *$ \\
\hline EPA+DHA LA & $\begin{array}{l}250 \mathrm{mg} \\
\text { Enerjinin \%4'ü }\end{array}$ & $\begin{array}{l}1.6 \mathrm{~g} \mathrm{n}-3(\mathrm{E}), 1.1 \mathrm{~g} \mathrm{n}-3(\mathrm{~K}) \\
14 \mathrm{~g} \mathrm{n}-6(\mathrm{E}), 11 \mathrm{~g} \mathrm{n}-6(\mathrm{~K})\end{array}$ \\
\hline Diyet posası & $25 \mathrm{~g}$ & $29 \mathrm{~g}(\mathrm{E}), 21 \mathrm{~g}(\mathrm{~K})$ \\
\hline Kalsiyum & $950 \mathrm{mg}$ & $1200 \mathrm{mg}$ \\
\hline Demir & $11 \mathrm{mg}$ & $10 \mathrm{mg}$ \\
\hline Magnezyum & $350 \mathrm{mg}(\mathrm{E}), 300 \mathrm{mg}(\mathrm{K})$ & $420 \mathrm{mg}(\mathrm{E}), 320 \mathrm{mg}(\mathrm{K})$ \\
\hline Fosfor & $550 \mathrm{mg}$ & $700 \mathrm{mg}$ \\
\hline Potasyum & $4.7 \mathrm{~g}$ & $4.7 \mathrm{~g}$ \\
\hline Selenyum & $70 \mu \mathrm{g}$ & $55 \mu \mathrm{g}$ \\
\hline Çinko & 9.4-16.3 mg (E), 7.5-12.7 mg (K) & $11 \mathrm{mg}(\mathrm{E}), 10 \mathrm{mg}(\mathrm{K})$ \\
\hline A vitamini & $750 \mu \mathrm{g}$ RE $(\mathrm{E}), 650 \mu \mathrm{g} \mathrm{RE}(\mathrm{K})$ & $900 \mu \mathrm{g}$ RE (E), $700 \mu \mathrm{g}$ RE (K) \\
\hline $\mathrm{B}_{1}$ vitamini & $1.2 \mathrm{mg}(\mathrm{E}), 1.1 \mathrm{mg}(\mathrm{K})$ & $1.2 \mathrm{mg}(\mathrm{E}), 1.1 \mathrm{mg}(\mathrm{K})$ \\
\hline $\mathrm{B}_{2}$ vitamini & $1.3 \mathrm{mg}(\mathrm{E}), 1.1 \mathrm{mg}(\mathrm{K})$ & $1.3 \mathrm{mg}(\mathrm{E}), 1.1 \mathrm{mg}(\mathrm{K})$ \\
\hline B $_{3}$ vitamini & $6.7 \mathrm{mg} \mathrm{NE} / 1000 \mathrm{kkal}$ & $16 \mathrm{mg}(\mathrm{E}), 14 \mathrm{mg}(\mathrm{K})$ \\
\hline B $_{6}$ vitamini & $1.7 \mathrm{mg}(\mathrm{E}), 1.5 \mathrm{mg}(\mathrm{K})$ & $1.7 \mathrm{mg}(\mathrm{E}), 1.5 \mathrm{mg}(\mathrm{K})$ \\
\hline Folat & $330 \mu \mathrm{g}$ & $400 \mu \mathrm{g}$ \\
\hline $\mathrm{B}_{12}$ vitamini & $4 \mu \mathrm{g}$ & $2.4 \mu \mathrm{g}$ \\
\hline C vitamini & $110 \mathrm{mg}(\mathrm{E}), 95 \mathrm{mg}(\mathrm{K})$ & $90 \mathrm{mg}$ \\
\hline D vitamini & $15 \mu \mathrm{g}(600 \mathrm{IU})$ & $10 \mu \mathrm{g}(400 \mathrm{IU})$ \\
\hline E vitamini & $13 \mathrm{mg}(\mathrm{E}), 11 \mathrm{mg}(\mathrm{K})$ & $15 \mathrm{mg}$ \\
\hline K vitamini & $120 \mu \mathrm{g}(\mathrm{E}), 90 \mu \mathrm{g}(\mathrm{K})$ & $120 \mu \mathrm{g}(\mathrm{E}), 90 \mu \mathrm{g}(\mathrm{K})$ \\
\hline
\end{tabular}

Amerika Beslenme Rehberi (2010) baskısının yayınlanmasından sonra, besin gruplarının günlük porsiyonlamasının kişiler tarafından daha iyi anlaşılabilmesi amaciyla besin rehberi olarak piramit modelinden tabak modeli olan 'MyPlate' uygulamasına geçilmiştir. Dört parçaya bölünmüş bir tabak (meyve, sebze, tahil ve protein grubu) ve bir bardaktan (süt grubu) oluşan şekliyle 'MyPlate' besin rehberi, kişilerin öğün düzenlemesini kolaylaştırmaktadır. Amerika Beslenme Rehberi 2020 verileriyle güncellenen 'MyPlate' uygulamasinda; internet sitesi üzerinden yaş, cinsiyet, boy uzunluğu, vücut ağırlığı, fiziksel aktivite verilerinin girilmesiyle, kişiler besin gruplarından günlük alması gereken porsiyonları ve örnek miktarları görebilmektedir. Öğün planlamada bu ve benzeri görsel uygulamalar, yaşlı kişiler tarafindan daha kolay anlaşılmakta, yeterli ve dengeli beslenmenin sağlanmasında kolay ve etkili bir yol olarak görünmektedir (USDA, 2021). 


\section{SONUÇ}

Yaşlı bireylerde yaşlanmaya bağlı oluşan fizyolojik değişimlerle birlikte, besin alımı ve fiziksel aktivite düzeyinin azalmasıyla yağ ve yağsız doku başta olmak üzere vücut kompozisyonu değişmektedir. Bu değişim, çeşitli sağlık sorunlarını tetikleyip beslenme yetersizliği, düşme, sakatlık gibi durumlara neden olabilmektedir. Öncelikle yaşl1 bireylerde malnütrisyon varlığının tespit edilmesi ve riskli gruplarda rutin tarama yapılması gerekmektedir. Tarama testi sonuçlarına göre malnütrisyon düzeyi ağırlaşmadan beslenme tedavisi planlanmalıdır. Bireylere düzenlenen beslenme programında yaşa bağlı gelişen iştahsızlık, çiğneme-yutma problemleri de göz önünde bulundurulup besinlerin daha kolay tüketilebilecek şekilde önerilmesi gerekebilmektedir. Yaşlı bireylerde kas yapımını destekleyecek ve vücuda gereksiz enerji alımı oluşturmayacak şekilde planlanan beslenme düzeninde, bireylerin diyetle yeterli enerji, kaliteli protein, D vitamini ve antioksidan özellikte olan A, C, E vitaminleri ve çinko, selenyum gibi besin ögelerini almış olduğundan emin olunması gerekmektedir. Yaşlılarda gelişen obezitede vücut ağırlığı yönetimi konusunda daha temkinli olunması gerekmektedir çünkü BKİ değerinin belli değerin üstünde olması (30 $\mathrm{kg} / \mathrm{m}^{2}$ üstü) kadar altında olması da $\left(21-22 \mathrm{~kg} / \mathrm{m}^{2}\right.$ altı) sağlık açısından tehlike oluşturmaktadır. Sarkopenik obezite grubunda hem sarkopeninin hem de obezitenin getirdiği fizyolojik yükle birlikte kronik hastalıkların görülme sıklığının arttığ görülmüştür, bu nedenle hastalık yönetimi ve hastalıklarda uygulanacak diyet tedavisi konusunda daha dikkatli olunması önemlidir. Ayrıca alanda çalışan sağlık profesyonellerinin sarkopenik obeziteye olan farkındalığının arttırılması yaşlı bireylerin yaşam kalitesinin artırılması için önem arz etmektedir. Diyet ve egzersiz birlikteliğiyle multidisipliner şekilde oluşturulacak kalıcı yaşam değişikliği, beraberinde sağlıklı bir yaşlılık süreci getirmekte ve ilerde oluşacak komplikasyonlar bu yolla en aza indirilebilmektedir.

\section{Yazar Katkısı / Author Contributions}

Fikir/Kavram: B. Ç., S. Ç.; Tasarım: B. Ç.; Denetleme/Danışmanlık: S. Ç.; Analiz ve/veya Yorum: B. Ç., S. Ç.; Kaynak Taraması: B. Ç.; Makalenin Yazımı: B. Ç.; Eleştirel İnceleme: S. Ç.

\section{Hakem Değerlendirmesi / Peer-review} Dış bağımsız.
Çıkar Çatışması / Conflict of Interest

Yazarlar araştırmanın yürütülmesinde herhangi bir çıkar çatışması olmadığını beyan etmiştir.

\section{Finansal Destek / Financial Disclosure}

Yazarlar araştırmanın yürütülmesi sürecinde bir finansal destek almadığını beyan etmiştir.

\section{KAYNAKLAR}

Abd Aziz, N. A. S., Mohd Fahmi Teng, N. I., Kamarul Zaman, M. (2019). Geriatric Nutrition Risk Index is comparable to the mini nutritional assessment for assessing nutritional status in elderly hospitalized patients. Clincal Nutrition ESPEN, 29, 77-85. doi:10.1016/j.clnesp.2018.12.002

Artaza-Artabe, I., Sáez-López, P., Sánchez-Hernández, N., Fernández-Gutierrez, N., Malafarina, V. (2016). The relationship between nutrition and frailty: Effects of protein intake, nutritional supplementation, vitamin D and exercise on muscle metabolism in the elderly: a systematic review. Maturitas, $93, \quad 89-99$. doi:10.1016/j.maturitas.2016.04.009

Atkins, J. L., Wannamathee, S. G. (2020). Sarcopenic obesity in ageing: cardiovascular outcomes and mortality. British Journal of Nutrition, 124(10), 1102-1113. doi:10.1017/s0007114520002172

Barkoukis, H. (2016). Nutrition recommendations in elderly and aging. The Medical Clinics of North America, 100(6), 1237-1250. doi:10.1016/j.mena.2016.06.006

Bauer, J., Biolo, G., Cederholm, T., Cesari, M., CruzJentoft, A. J., MorleyI. E., ... Boirie, Y. (2013). Evidence-based recommendations for optimal dietary protein intake in older people: a position paper from the PROT-AGE Study Group. Journal of The American Medical Directors Association, 14(8), 542-559. doi: 10.1016/j.jamda.2013.05.021

Bauer, J. M., Kaiser, M. J., Anthony, P., Guigoz, Y., Sieber, C. C. (2008). The mini nutritional assessment ${ }^{\circledR}$ - its history, today's practice, and future perspectives. Nutrition in Clinical Practice, 23(4), 388-396. doi:10.1177/0884533608321132

Baum, J. I., Kim, I.-Y., Wolfe, R. R. (2016). Protein consumption and the elderly: What is the optimal level of intake? Nutrients, 8(6), 359. doi: 10.3390/nu8060359

Baumgartner, R. N. (2000). Body composition in healthy aging. Annals of the New York Academy of Sciences, 904(1), 437-448.

Besler, H., Rakıcıoğlu, N., Ayaz, A., Büyüktuncer Demirel, Z., Gökmen Özel, H., Samur, F., . . . Göktaş, Z. (2015). Türkiye'ye Özgü Besin ve Beslenme Rehberi. Hacettepe Üniversitesi Sağlık 
Bilimleri Fakültesi Beslenme ve Diyetetik Bölümü, Ankara.

Beaudart, C., Locquet, M., Touvier, M., Reginster, J. Y., Bruyère, O. (2019). Association between dietary nutrient intake and sarcopenia in the SarcoPhAge study. Aging Clinical and Experimental Research, 31(6), 815-824. doi: 10.1007/s40520-019-01186-7

Björkman, M. P., Suominen, M. H., Kautiainen, H., Jyväkorpi, S. K., Finne-Soveri, H. U., Strandberg, T. E., . . . Tilvis, R. S. (2020). Effect of protein supplementation on physical performance in older people with sarcopenia-a randomized controlled trial. Journal of the American Medical Directors Association, 21(2), 226-232.e221. doi:10.1016/j.jamda.2019.09.006

Bo, Y., Liu, C., Ji, Z., Yang, R., An, Q., Zhang, X., . . . Lu, Q. (2019). A high whey protein, vitamin D and E supplement preserves muscle mass, strength, and quality of life in sarcopenic older adults: a doubleblind randomized controlled trial. Clinical Nutrition, $\quad 38(1), \quad 159-164$ doi:10.1016/j.clnu.2017.12.020

Bouillanne, O., Morineau, G., Dupont, C., Coulombel, I., Vincent, J. P., Nicolis, I., ... Aussel, C. (2005). Geriatric Nutritional Risk Index: a new index for evaluating at-risk elderly medical patients. The American Journal of Clinical Nutrition, 82(4), 777 783. doi:10.1093/ajcn/82.4.777

Cardon-Thomas, D. K., Riviere, T., Tieges, Z., Greig, C. A. (2017). Dietary protein in older adults: adequate daily intake but potential for improved distribution. Nutrients, 9(3), 184. doi: 10.3390/nu9030184

Clegg, M. E., Williams, E. A. (2018). Optimizing nutrition in older people. Maturitas, 112, 34-38. doi: 10.1016/j.maturitas.2018.04.001

Corcoran, C., Murphy, C., Culligan, E. P., Walton, J., Sleator, R. D. (2019). Malnutrition in the elderly. Science Progress, 102(2), 171-180. doi:10.1177/0036850419854290

Cruz-Jentoft, A. J., Baeyens, J. P., Bauer, J. M., Boirie, Y., Cederholm, T., Landi, F., . . . Schneider, S. M. (2010). Sarcopenia: European consensus on definition and diagnosis report of the European Working Group on Sarcopenia in older people. Age and Ageing, 39(4), 412-423. doi: 10.1093/ageing/afq034

Cruz-Jentoft, A. J., Bahat, G., Bauer, J., Boirie, Y., Bruyère, O., Cederholm, T., ... Zamboni, M. (2019). Sarcopenia: revised European consensus on definition and diagnosis. Age and Ageing, 48(1), 16-31. doi: 10.1093/ageing/afy 169

Dhillon, R. J., Hasni, S. (2017). Pathogenesis and management of sarcopenia. Clinics in Geriatric
Medicine, 33(1),

doi:10.1016/j.cger.2016.08.002

17-26.

Dodds, R. M., Syddall, H. E., Cooper, R., Benzeval, M., Deary, I. J., Dennison, E. M., ... Sayer, A. A. (2014). Grip strength across the life course: normative data from twelve British studies. PloS One, 9(12), e113637. doi: 10.1371/journal.pone.0113637

Dupont, J., Dedeyne, L., Dalle, S., Koppo, K., Gielen, E. (2019). The role of omega-3 in the prevention and treatment of sarcopenia. Aging Clinical and Experimental Research, 31(6), 825-836. doi:10.1007/s40520-019-01146-1

European Food Safety Authority (2019). Interactive tool - Dietary reference values. Erişim tarihi: 02.09.2021,

https://www.efsa.europa.eu/en/topics/topic/dietaryreference-values

El Hajj, C., Fares, S., Chardigny, J. M., Boirie, Y., Walrand, S. (2018). Vitamin D supplementation and muscle strength in pre-sarcopenic elderly Lebanese people: a randomized controlled trial. Archives of Osteoporosis, 14(1), 4. doi:10.1007/s11657-018-0553-2

Ganapathy, A., Nieves, J. W. (2020). Nutrition and sarcopenia-what do we know? Nutrients, 12(6), 1755. doi: $10.3390 /$ nu 12061755

Hayashi, A. P., de Capitani, M. D., Dias, S. F., de Souza Gonçalves, L., Fernandes, A. L., Jambassi-Filho, J. C., . . . Roschel, H. (2020). Number of high-protein containing meals correlates with muscle mass in pre-frail and frail elderly. European Journal of Clinical Nutrition, 74(7), 1047-1053. doi:10.1038/s41430-020-0618-3

Hsu, K. J., Liao, C. D., Tsai, M. W., Chen, C. N. (2019). Effects of exercise and nutritional intervention on body composition, metabolic health, and physical performance in adults with sarcopenic obesity: a meta-analysis. Nutrients, 11(9). doi:10.3390/nu11092163

Jones, C. J., Rikli, R. E., Beam, W. C. (1999). A 30-s chair-stand test as a measure of lower body strength in community-residing older adults. Research Quarterly for Exercise and Sport, 70(2), 113-119. doi: 10.1080/02701367.1999.10608028

Juby, A. G., Mager, D. R. (2019). A review of nutrition screening tools used to assess the malnutritionsarcopenia syndrome (MSS) in the older adult. Clinical Nutrition ESPEN, 32, 8-15. doi: 10.1016/j.clnesp.2019.04.003

Keller, U. (2019). Nutritional laboratory markers in malnutrition. Journal of Clinical Medicine, 8(6), 775. doi: 10.3390/jem8060775

Khor, E. Q., Lim, J. P., Tay, L., Yeo, A., Yew, S., Ding, Y. Y., Lim, W. S. (2020). Obesity definitions in sarcopenic obesity: differences in prevalence, 
agreement and association with muscle function. Journal of Frailty \& Aging, 9(1), 37-43. doi:10.14283/jfa.2019.28

Kiesswetter, E., Sieber, C. C., Volkert, D. (2020). Protein intake in older people : why, how much and how? Zeitschrift für Gerontologie und Geriatrie, 53(4), 285-289. doi:10.1007/s00391-020-01723-4

Kim, T. N. (2018). Elderly obesity: is it harmful or beneficial? Journal of Obesity \& Metabolic Syndrome, 27(2), 84-92. doi:10.7570/jomes.2018.27.2.84

Leij-Halfwerk, S., Verwijs, M. H., van Houdt, S., Borkent, J. W., Guaitoli, P., Pelgrim, T., . . Corish, C. A. (2019). Prevalence of protein-energy malnutrition risk in European older adults in community, residential and hospital settings, according to 22 malnutrition screening tools validated for use in adults $\geq 65$ years: a systematic review and meta-analysis. Maturitas, 126, 80-89. doi: 10.1016/j.maturitas.2019.05.006

Liao, C. D., Chen, H. C., Huang, S. W., Liou, T. H. (2019). The role of muscle mass gain following protein supplementation plus exercise therapy in older adults with sarcopenia and frailty risks: a systematic review and meta-regression analysis of randomized trials. Nutrients, 11(8). doi:10.3390/nu11081713

Liao, C. D., Tsauo, J. Y., Wu, Y. T., Cheng, C. P., Chen, H. C., Huang, Y. C., . . Liou, T. H. (2017). Effects of protein supplementation combined with resistance exercise on body composition and physical function in older adults: a systematic review and meta-analysis. American Journal of Clinical Nutrition, 106(4), 1078-1091. doi:10.3945/ajen.116.143594

Lim, H. S., Park, Y. H., Suh, K., Yoo, M. H., Park, H. K., Kim, H. J., . . B Byun, D. W. (2018). Association between sarcopenia, sarcopenic obesity, and chronic disease in korean elderly. Journal of Bone Metabolism, 25(3), 187-193. doi:10.11005/jbm.2018.25.3.187

Lonnie, M., Hooker, E., Brunstrom, J. M., Corfe, B. M., Green, M. A., Watson, A. W., . . Johnstone, A. M. (2018). Protein for life: review of optimal protein intake, sustainable dietary sources and the effect on appetite in ageing adults. Nutrients, 10(3), 360. doi: $10.3390 /$ nu 10030360

Maeda, K., Akagi, J. (2016). Treatment of sarcopenic dysphagia with rehabilitation and nutritional support: a comprehensive approach. Journal of the Academy of Nutrition and Dietetics, 116(4), 573577. doi: 10.1016/j.jand.2015.09.019

Martin, H., Aihie Sayer, A., Jameson, K., Syddall, H., Dennison, E. M., Cooper, C., Robinson, S. (2011). Does diet influence physical performance in community-dwelling older people? Findings from the Hertfordshire Cohort Study. Age and Ageing, 40(2), 181-186. doi: 10.1093/ageing/afq175

Montiel-Rojas, D., Nilsson, A., Santoro, A., Franceschi, C., Bazzocchi, A., Battista, G., . . . Kadi, F. (2020). Dietary fibre may mitigate sarcopenia risk: findings from the NU-AGE cohort of older European adults. Nutrients, 12(4), 1075. doi: 10.3390/nu12041075

Morley, J. E. (2016). Frailty and sarcopenia in elderly. Wiener Klinische Wochenschrift, 128(Suppl 7), 439-445. doi:10.1007/s00508-016-1087-5

Nie, C., He, T., Zhang, W., Zhang, G., ve Ma, X. (2018). Branched chain amino acids: beyond nutrition metabolism. International Journal of Molecular Sciences, 19(4), 954. doi: 10.3390/ijms 19040954

Öztürk, Z. A., Türkbeyler İ, H., Abiyev, A., Kul, S., Edizer, B., Yakaryılmaz, F. D., Soylu, G. (2018). Health-related quality of life and fall risk associated with age-related body composition changes; sarcopenia, obesity and sarcopenic obesity. Internal Medicine Journal, 48(8), 973-981. doi:10.1111/imj.13935

Park, Y., Choi, J. E., Hwang, H. S. (2018). Protein supplementation improves muscle mass and physical performance in undernourished prefrail and frail elderly subjects: a randomized, doubleblind, placebo-controlled trial. The American Journal of Clinical Nutrition, 108(5), 1026-1033. doi: 10.1093/ajen/nqy214

Picetti, D., Foster, S., Pangle, A. K., Schrader, A., George, M., Wei, J. Y., Azhar, G. (2017). Hydration health literacy in the elderly. Nutrition and Healthy Aging, 4, 227-237. doi:10.3233/NHA-170026

Prokopidis, K., Cervo, M. M., Gandham, A., Scott, D. (2020). Impact of protein intake in older adults with sarcopenia and obesity: a gut microbiota perspective. Nutrients, 12(8), 2285. doi: 10.3390/nu12082285

Rath, P. (2019). Nutrition for elderly. In P. C. Rath (Ed.), Models, Molecules and Mechanisms in Biogerontology: Physiological Abnormalities, Diseases and Interventions (pp. 411-426). Singapore: Springer Singapore.

Reinders, I., Wijnhoven, H. A., Jyväkorpi, S. K., Suominen, M. H., Niskanen, R., Bosmans, J. E., ... Visser, M. (2020). Effectiveness and costeffectiveness of personalised dietary advice aiming at increasing protein intake on physical functioning in community-dwelling older adults with lower habitual protein intake: rationale and design of the PROMISS randomised controlled trial. British Medical of Journal Open, 10(11), e040637. doi: 10.1136/bmjopen-2020-040637. 
Rusu, A., Randriambelonoro, M., Perrin, C., Valk, C., Álvarez, B., Schwarze, A.-K. (2020). Aspects influencing food intake and approaches towards personalising nutrition in the elderly. Journal of Population Ageing, 1-18. doi: 10.1007/s12062-01909259-1

Sağlık Bakanlığı (2016). Türkiye Beslenme Rehberi TÜBER 2015. TC Să̆lık Bakanliğı Yayını No:1031, Ankara

Santos, V. R. D., Christofaro, D. G. D., Gomes, I. C., Júnior, I. F. F., Gobbo, L. A. (2018). Relationship between obesity, sarcopenia, sarcopenic obesity, and bone mineral density in elderly subjects aged 80 years and over. Revista Brasileira de Ortopedia, 53(3), 300-305. doi:10.1016/j.rboe.2017.09.002

Seino, S., Sumi, K., Narita, M., Yokoyama, Y., Ashida, K., Kitamura, A., Shinkai, S. (2018). Effects of lowdose dairy protein plus micronutrient supplementation during resistance exercise on muscle mass and physical performance in older adults: a randomized, controlled trial. The Journal of Nutrition Health and Aging, 22(1), 59-67. doi:10.1007/s12603-017-0904-5

Siddique, N., O'Donoghue, M., Casey, M. C., Walsh, J. B. (2017). Malnutrition in the elderly and its effects on bone health - A review. Clinical Nutrition ESPEN, 21, 31-39. doi:10.1016/j.clnesp.2017.06.001

Son, J., Yu, Q., Seo, J. S. (2019). Sarcopenic obesity can be negatively associated with active physical activity and adequate intake of some nutrients in Korean elderly: findings from the Korea National Health and Nutrition Examination Survey (20082011). Nutrition Research and Practice, 13(1), 47 57. doi:10.4162/nrp.2019.13.1.47

Studenski, S. A., Peters, K. W., Alley, D. E., Cawthon, P. M., McLean, R. R., Harris, T. B., . . Kenny, A. M. (2014). The FNIH sarcopenia project: rationale, study description, conference recommendations, and final estimates. Journals of Gerontology Series A: Biomedical Sciences and Medical Sciences, 69(5), 547-558. doi: 10.1093/gerona/glu010

Sulmont-Rossé, C. (2020). Eating in the elderly. Handbook of Eating and Drinking: Interdisciplinary Perspectives, 433-457.

Türkiye İstatistik Kurumu. (2020). İstatistiklerle Yaşlilar. Erişim tarihi: 28.04.2021, https://data.tuik.gov.tr/Bulten/Index?p=Istatistikler le-Yaslilar-2020-37227

US Department of Agriculture (2020). US Department of Health and Human Services-Dietary Guidelines for Americans, 2020-2025. Erişim tarihi: 02.09.2021,

https://dietaryguidelines.gov/sites/default/files/202 1-03/Dietary_Guidelines_for_Americans-20202025.pdf
US Department of Agriculture (2021). Erişim tarihi: 04.09.2021, https://www.myplate.gov/myplateplan

Verlaan, S., Aspray, T. J., Bauer, J. M., Cederholm, T., Hemsworth, J., Hill, T. R., ... Brandt, K. (2017). Nutritional status, body composition, and quality of life in community-dwelling sarcopenic and nonsarcopenic older adults: A case-control study. Clinical Nutrition, 36(1), 267-274. doi: 10.1016/j.clnu.2015.11.013

Verlaan, S., Maier, A. B., Bauer, J. M., Bautmans, I., Brandt, K., Donini, L. M., ... Cederholm, T. (2018). Sufficient levels of 25-hydroxyvitamin D and protein intake required to increase muscle mass in sarcopenic older adults-The PROVIDE study. Clinical Nutrition, 37(2), 551-557. doi: 10.1016/j.clnu.2017.01.005

Veronese, N., Berton, L., Carraro, S., Bolzetta, F., De Rui, M., Perissinotto, E., ... Sergi, G. (2014). Effect of oral magnesium supplementation on physical performance in healthy elderly women involved in a weekly exercise program: a randomized controlled trial. The American Journal of Clinical Nutrition, 100(3), 974-981. doi: 10.3945/ajen.113.080168

Wakabayashi, H., Kishima, M., Itoda, M., Fujishima, I., Kunieda, K., Ohno, T., . . . D. (2021). The Japanese working group on sarcopenic, diagnosis and treatment of sarcopenic dysphagia: a scoping review. Dysphagia, 36(3), 523-531. doi:10.1007/s00455-021-10266-8

Welch, A. A., Jennings, A., Kelaiditi, E., Skinner, J., Steves, C. J. (2020). Cross-sectional associations between dietary antioxidant vitamins $\mathrm{C}, \mathrm{E}$ and carotenoid intakes and sarcopenic indices in women aged 18-79 years. Calcified Tissue International, 106(4), 331-342. doi: 10.1007/s00223-019-00641-x

World Health Organisation. (2017). World health statistics. Life expectancy and healthy life expectancy. Erişim tarihi: 19.04.2021 https://apps.who.int/gho/data/node.main.SDG2016 LEX?lang=en

World Health Organization. (2015). World report on ageing and health. Erişim tarihi: 04.09.2021 https://apps.who.int/iris/handle/10665/186463

Yang, L.-J., Wu, G.-H., Yang, Y.-L., Wu, Y.-H., Zhang, L., Wang, M.-H., . . . Weng, X.-F. (2019). Nutrition, physical exercise, and the prevalence of sarcopenia in elderly residents in nursing homes in China. Medical Science Monitor : International Medical Journal of Experimental And Clinical Research, 25, 4390-4399. doi:10.12659/MSM.914031

Zhang, X., Xie, X., Dou, Q., Liu, C., Zhang, W., Yang, Y., . . . Cheng, A. S. (2019). Association of sarcopenic obesity with the risk of all-cause 
BANÜ Sağlık Bilimleri ve Araştırmaları Dergisi / BANU Journal of Health Science and Research • 3(3) • 2021

mortality among adults over a broad range of different settings: a updated meta-analysis. $B M C$ Geriatrics, 19(1), 1-14. doi: 10.1186/s12877-0191195-y 